of the initial stages of Methodist Mission work in the Union; of welfare organization in the Eastern Cape; of the influence of frontier opinion on the policy of the Legislative Council and Cape Parliament.

The following full-time research workers have been appointed:

Mr. G. S. Lumsden, M.A. (S.A.), economist in the Border Regional Survey.

Dr. D. H. Reader, M.A., Ph. D. (Cantab.), anthropologist in the Border Regional Survey.

Mr. P. Kopo and Mr. G. Magqwashe, research assistants in the Border Regional Survey.

Miss L. Jacob, B.A. (Rhodes), anthropologist holding a Nuffield Research Scholarship (since resigned on health grounds).

Mr. C. Board, B.A. (Hons.) (London), geographer in the Border Regional Survey.

Mr. E. T. Sherwood, B.A. (Hons.) (Queen's, Canada), appointed Senior Research Fellow and Secretary of the Institute.

Miss M. C. Nongauza, B.A. (S.A.), U.E.D., B.Ed. (Cape Town), appointed to work on African education, holding a Nuffield Research Scholarship.

Another anthropologist is to be appointed.

In addition, several members of the University staff and a number of post-graduate students are giving voluntary part-time service in one or other of the research activities.

PhILIP MAYer

\title{
Community Development in the Pare district of Tanganyika
}

THE October 1955 issue of UNESCO's Fundamental and Adult Education includes an account of a community development scheme carried on during the period $1950-4$ in the Pare District of north-east Tanganyika. Following a report made by Professor C. N. Phillips of London University, who visited Tanganyika in 1947, it was decided to organise a mass education scheme, with the emphasis on mass literacy, in the North Pare Mountains, as a pilot project for the whole territory. Six African welfare workers were trained at Dar-es-Salaam and were posted to North Pare in 1949 with a welfare officer in charge of the team. A social survey of the hill areas was carried out, and a literacy survey revealed that about so per cent. of the men and 80 per cent. of the women in the area were illiterate. After some initial difficulties the scheme finally got under way in the latter part of 1950; the Social Welfare department having been reorganized as the Social Development department, Mr. Mason, a social development officer with considerable experience of adult education, was put in charge of the team.

By the beginning of I95 I there were I, 500 learners, mostly women and girls, being taught in the literacy campaign, and by March 143 had passed their simple tests of literacy and had been presented with their literacy certificates. Mr. Mason, in charge of the scheme, lived on the spot at Usangi in the North Pare Mountains and his trained African staff were assigned to parishes. Village committees, under the chairmanship of village headmen and with links to chiefdom committees for the two chiefdoms involved (Usangi and Ugweno), assisted in encouraging the campaign. The learners themselves met in informal groups in any convenient place-a building, a veranda, often under a tree- to be taught by volunteer teachers supervised by the peripatetic paid staff.

During 195 I the campaign spread down the mountain slopes to the foothills and plains below, and by the end of the year almost the whole of the two chiefdoms of North Pare were covered by groups. These new groups were mainly formed as a result of local initiative and enterprise, the arrangements of time and place for classes and for volunteer leaders being made by the people themselves.

Meanwhile in the hills, many of the original groups were closed down because their 
members had either become literate or had lost interest. These were replaced by new groups in pockets not previously covered and by second stage groups (shule ya jux) providing further instruction and practice in reading, writing and arithmetic.

By the end of I95 I 3,500 literacy primers had been sold and 36r literacy certificates had been issued. During 1952 the campaign reached Middle Pare and the South Pare Mountains and by December $1952 \mathrm{Mr}$. Mason had records of some 120 literacy groups with about 2,000 attending; by the end of the year a total of 850 literacy certificates had been issued since the start of the campaign.

During 1953 the campaign took in the extreme south of the district which had not previously been covered. By this time, however, the tempo of the campaign had slowed down considerably due to a variety of factors-two of them being a poor agricultural season and a rather less enthusiastic response to the campaign on the part of the people of the more southerly areas who are considerably more backward than their fellow tribesmen of the north. During 1954 the campaign, in so far as official encouragement and support were concerned, was finally wound up, by which time 1,322 literacy certificates had been issued since the start of the campaign.

Mr. Mason wrote a detailed report in I95I on the methods used in the campaign up to that time. These methods changed but little right up to the end of the campaign except that, as the groups spread more widely over the district, supervision and control tended to become more and more tenuous. Thus in the later stages of the campaign almost all teaching was done by volunteer leaders while the trained staff toured the many and widely dispersed groups as much as they could. Visits from the Social Development Officer, District Commissioner, chiefs and other prominent persons were found to be one of the most important factors in maintaining the enthusiasm of the learners, but such visits became more difficult as the groups grew more numerous and widespread.

A monthly district newspaper in Swahili was founded by the Social Development Team in April I95I, to provide follow-up literature, to stimulate community development, and as a valuable project in itself. The first issues of Habari za Upare were cyclostyled and illustrated with photographs stuck in by hand. Circulation was only a few hundred copies. The paper has since grown to a 12-page ( $16 \times \mathrm{I} \mathrm{r}$ in.) paper, printed in the neighbouring town of Moshi, profusely illustrated and well on the way to earning enough revenue from advertising and sales to be self-supporting. Circulation is now in the neighbourhood of 3,000 copies per month. The paper has naturally always made a special feature of the mass literacy campaign and other community development activities. Habari za Upare has now been largely handed over by the Social Development Officer to the Pare Council, who employ their own full-time editor.

The supply of other types of follow-up literature has always presented something of a problem. The reading and writing of letters must provide by far the most important form of follow-up for new literates, and the ability to exchange letters was often given as their motive by adult learners. Apart from letters and Habari za Upare, the other vernacular newspapers form an important source of follow-up literature; these are the Tanganyika Government's popular Mambo Leo (monthly) and the weekly Habari za Leo, the East African Literature Bureau's weekly Tazama, and the publication Siku Hizi.

\section{Social and Economic Studies in Leopoldville, Belgian Congo}

THE Conference of the Inter-african Committee on Social Sciences held at Bukavu in August 1955 is expected to give a fresh stimulus to economic and social research in the Leopoldville area. Nevertheless some work had already been done. In July and August 1952, in connexion with the Ten-Year Development Plan, an extensive survey of the African labour force was 